\title{
TOWARDS A GREEN ECONOMY: THE REPUBLIC OF BELARUS
}

\author{
Larisa Marchenko ${ }^{1}$, Viktoriya Podgornaya ${ }^{2}$, Volga Bashlakova ${ }^{3}$, Alla Suvorova ${ }^{4}$ \\ ${ }^{I}$ Ph.D. of Technics, Associate Professor, Head of the Department of Fundamental and Applied Mathematics of the Fac- \\ ulty Mathematics and Programming technologies, Francisk Skorina Gomel State University, Gomel, Belarus, Phone \\ +375 (29)6182928. Email: Imarchenko@gsu.by \\ ${ }^{2}$ Ph.D. of Physics and Mathematics, Associate Professor, Head of scientific-organizational and innovative activity De- \\ partment, V.A. Belyi Metal-polymer Research Institute of National Academy of Sciences of Belarus, Gomel, Belarus \\ Phone: +375 (29) 31181 04. Email: vvpodgornaya@tut.by
}

${ }^{3}$ Ph.D. in Economics, Associate Professor,Economic Theory and World Economy Department, Faculty of Economics, Francisk Skorina Gomel State University, Gomel, Belarus. Email: minsk4@ rambler.ru

${ }^{4}$ Ph.D. of Physics and Mathematics, Associate Professor,Primrose School of Clear Lake, Houston, Texas, the United States of America, Phone +1 (832)288 15 57. Email: suvorova@mail.com

Received 3103 2021; Accepted 13042021

\begin{abstract}
It is almost impossible to develop a universal approach to the formation of a green economy at the regional level, characterized by differences in economic specialization, heterogeneity of investment activity, and a variety of natural conditions. In this regard, this article aims to provide an analysis of the recent level of development of the green economy in the Republic of Belarus based on indicators of the green economy for the development of competent management decisions. The authors studied the indicators of the green economy in the Republic of Belarus using data mining methods. The relationships between the rates of change of indicators were established, and the uniformity of their development was researched. Trends in indicators were revealed. Based on the research results, reasoned conclusions were made. Measures aimed at solving the identified problems were proposed.
\end{abstract}

Keywords: green economy, indicator, rate of change, relationship, region, regional level. JEL Codes: C13, C18.

\section{Introduction}

A foundation for countries to achieve high positions in the rating on indicators of green economy development is the orientation of national policy on the results of scientific research by leading European, American and Asian scientists who develop tools and effective management technologies, as well as study the validity and feasibility of the world economy's movement towards sustainable development and, in particular, towards a green economy. Examples of such researches are the works of Makiela and Misztur (2012). Makiela and Misztur (2012) reveal the essence of sustainable economic development, main problems, prospects, directions, outline the basics of effective management of the green economy. The work of Bashorin O. V. (2012) is devoted to the peculiarities of the transition to a green economy at the international and regional levels. In the Russian Federation the works of Porfiriev B. N. (2013), Kozhevnikova T. M. (2013) are devoted to the research of sustainable development. At the regional level, sustainable development is considered in the work of S. N. Kozlov (2020). Bobylev (2019) identified green economy indicators and sustainable development goals. He also proposed

Copyright (C 2021 Author(s), published by Vytautas Magnus University. This is an open access article distributed under the terms of the Creative Commons Attribution Non-Commercial 4.0 (CC BY-NC 4.0) license, which permits unrestricted use, distribution, and reproduction in any medium provided the original author and source are credited. The material cannot be used for commercial purposes. 
a system of indicators for assessing the sustainable development of cities.

Rybak, Grib, and Shokr (2016) investigated the phenomenon of a "green economy" in the Republic of Belarus. They proposed calculated indicators of waste-free, energy-intensive, eco-economic efficiency, and land-intensity on the example of the Republic of Belarus. Lednitsky and Protas (2019) have developed the National Action Plan to Implement the Principles of Green Economy in Forestry in the Republic of Belarus until 2030. Many authors have considered the analysis of the forecast assessment of the sustainable development of the green economy by branches of economic activity of the Republic of Belarus. The analysis of published works on the subject of the study shows that many scientific papers in the Republic of Belarus are devoted to the analysis of the problems of the green economy. However, there are no studies of the development of indicators of the green economy in dynamics and in the relationship, which can be carried out using data mining methods.

The purpose of this research is to study the trends and state of development of the green economy in the Republic of Belarus, identify problems and potential solutions, as well as develop new knowledge in the field of a green economy.

The object of the research is the process of forming the green economy of the Republic of Belarus. The subject of research is the dynamics, relationships, and prospects for the development of the green economy in the Republic of Belarus.

Research methods are based on foreign and Belarusian scientific literature, analysis of statistical data for 9 years (National Statistical...).

Practical application is the main provisions and conclusions of the article can be used for preparing analytical materials and making competent management decisions.

The hypothesis is put forward that the study of the dynamics of indicators does not reveal the real situation about the development of the green economy, so it is necessary to study the rate of change of indicators, as well as their relationship. The hypothesis is supported by the use of data mining methods. The analysis results are based on calculations of official indicators (National Statistical...).

\section{Methodology}

The process of forming a green economy requires studying the dynamics, growth rates, and relationships between indicators in order to identify "bottlenecks". We suggest using data mining, which will provide a real opportunity to determine the effectiveness of the formation of the green economy. Our method combines traditional methods (tabular, comparative, and generalizing) with data mining methods. To identify differences between the rates of change of indicators, the Mann-Whitney test was used at a significance level of 0.05. Statistical correlation of indicators was established using the Spearman test. The information base for this article consists of scientific publications of foreign and Belarusian authors, official data of the National Statistical Committee of the Republic of Belarus, and resources of the global Internet. The calculations are made in Statistica. The research is based on statistical data from the National Statistical Committee of the Republic of Belarus (National Statistical...).

\section{Research results and discussion}

Belarus considers the green economy as an important tool for ensuring sustainable development and environmental security of the republic. The government of the country is taking consistent measures to introduce green (environmental) principles into the national economy. The first steps to implement green economy principles were established in (Directive ..., 2007; Program ..., 2016). In (Program ..., 2016) the National Action Plan for the development of a "green" economy in the Republic of Belarus until 2020 was approved. Implementation of the principles of the green economy is carried out in the following sectors: waste management, "green" energy, "green" transport, organic agriculture, environmentally safe chemical and biological industries, "green" house, education for sustainable development, ecotourism. 
The principles of the green economy are integrated into the document (the latest in the literature document (Nacional'nyj..., 2017), which reflects the three components of sustainable development: "human - economy - environment". Key measures include the use of economic policies and tools, education for a green economy, and science and innovation.

Document (Nacional'nyj ..., 2017) presents the goals, tasks, tools, and mechanisms for implementing key strategic directions that ensure sustainable development of the Republic of Belarus in the context of its three components (human, economy, environment) (taking into account the achievement of sustainable development goals, has further developed the NSSD-2030.)

The Republic of Belarus monitors the transition to a green economy via green growth indicators, which characterize the processes of greening the economy through the conservation and rational use of natural resources and the impact of these processes on the development of the social sphere. These indicators were formed in accordance with the Guidelines prepared by the Organization for economic cooperation and development for the Eastern Partnership countries.

The dynamics and rate of change of the selected indicators and the relationship between some of them are studied in this article.

The dynamics of Socio-economic indicators in the Republic of Belarus for the period 2010 - 2018 were considered (figure 1-4). Important indicators of the social component are coefficient of population aging, average annual population size, life expectancy at birth.

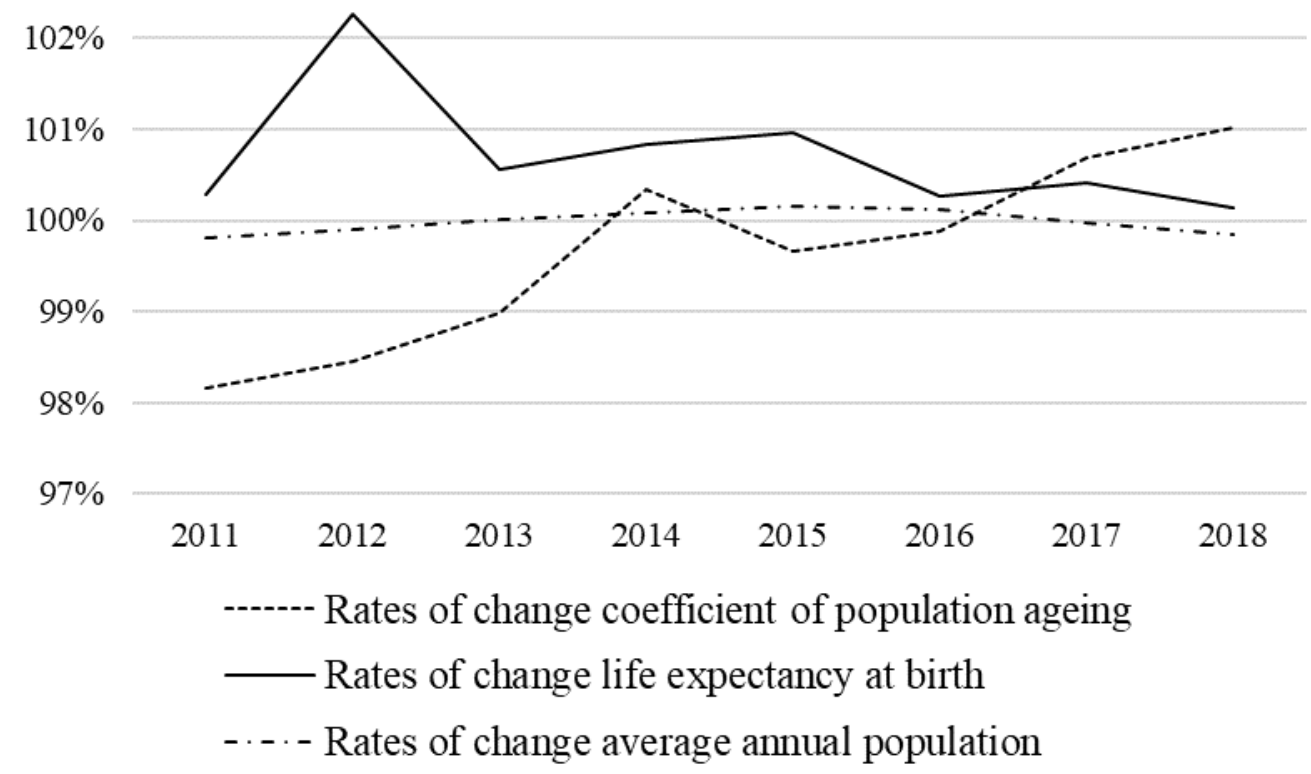

Figure 1. Changes in the aging rate, life expectancy and average annual population

There is a linear trend of changes in the rate of population aging, which indicates the nonlinear dynamics of this indicator. The aging rate of the population changed from 0.925 to 0.899 in the period from 2010 to 2018 , which is $97.19 \%$.
Analysis of growth rates allows us to see indicators whose growth slowed down, which requires finding ways to influence changes in the behavior of these indicators. An increase in the rate of growth of the population aging quotient and a decrease in the rate of growth in life

Copyright (C) 2021 Author(s), published by Vytautas Magnus University. This is an open access article distributed under the terms of the Creative Commons Attribution Non-Commercial 4.0 (CC BY-NC 4.0) license, which permits unrestricted use, distribution, and reproduction in any medium provided the original author and source are credited. The material cannot be used for commercial purposes. 
expectancy (compared to world leaders) requires additional attention from the government. At the significance level of 0.05 by Mann-Whitney test (U test), the equality of the average rates of change of the considered indicators is shown.

The green economy is characterized by the development of a knowledge economy, with the following important indicators:

- level of registered unemployment;

- access to education characterized by the ratios of graduates with higher education from higher education institutions;

- ratio of graduates from institutions of secondary special education.

The Gini coefficient shows the degree of deviation of the actual distribution of total available resources (income) of the population from the line of their uniform distribution (from 0 to 1 , that is, the closer the indicator value is to 1 , the more unequally resources (income) are distributed in society). We will look at the pace of these indicators (figure 2). Changes in the unemployment rate are more volatile than changes in the Gini coefficient and access to higher education. Maintaining the system of secondary vocational education had led to a positive correlation of the growth rate of the Gini coefficient with the growth rate of the ratio of graduates from institutions of secondary special education (corr $=0,33$ ). There is a negative correlation between the Gini coefficient growth rate and the ratio of graduates from higher education institutions (corr $=-0,32$ ). The average value of the Gini coefficient for 2010-2018 is 0.28 . We note that the growth rate of the unemployment rate is positively correlated with the rate of graduation of specialists from higher education institutions (corr $=0.15$ ). The difference in the average rate of change of the considered indicators is confirmed with a confidence of 0.05 (the Mann-Whitney U test).

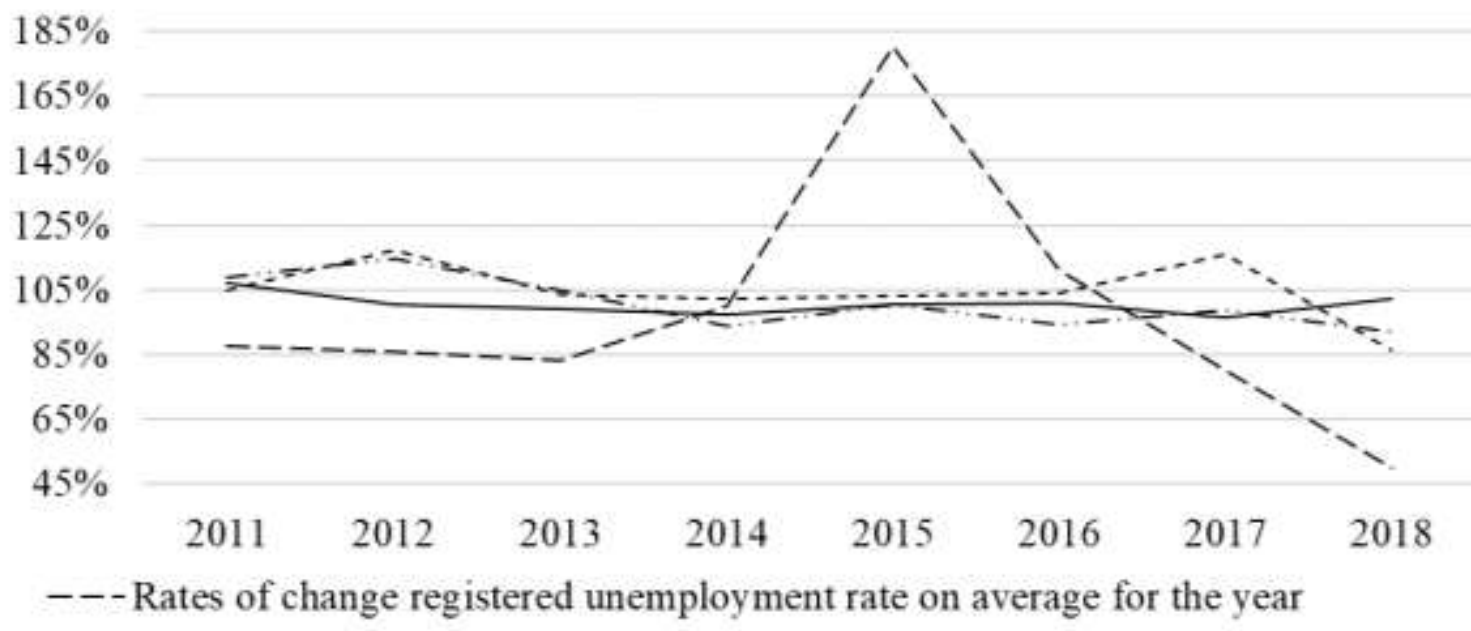

-..- Rates of change access to education: graduation rate of specialists with a higher education diploma from higher education institutions

$-\cdots-$ Rates of change access to education: graduation rate of specialists from institutions of secondary special education

- Rates of change the Gini coefficient

Figure 2. Rates of change of unemployment, access to higher and secondary special education, and the Gini coefficient

Changes in the basic indicators of the economy (gross domestic product (GDP), net national income (NNI), labor productivity, the volume of foreign trade in goods and services to GDP. The consumer price index) in the Republic of Belarus are co-directional (figure 3). 
The growth rate of net national income, labor productivity by GDP, and the volume of foreign trade in goods and services to GDP declined in 2013 and stabilized at the level of $105 \%$ to $115 \%$ starting in 2015 . There is a high correlation between the growth rate of net national income and labor productivity in GDP (corr $=0.99)$. The consumer price index is positively correlated with the growth rate of GDP (corr $=0.98)$, net national income (corr $=0.96$ ), labor productivity by GDP (corr $=0.98)$, and the volume of foreign trade in goods and services to GDP (corr $=0.33$ ).

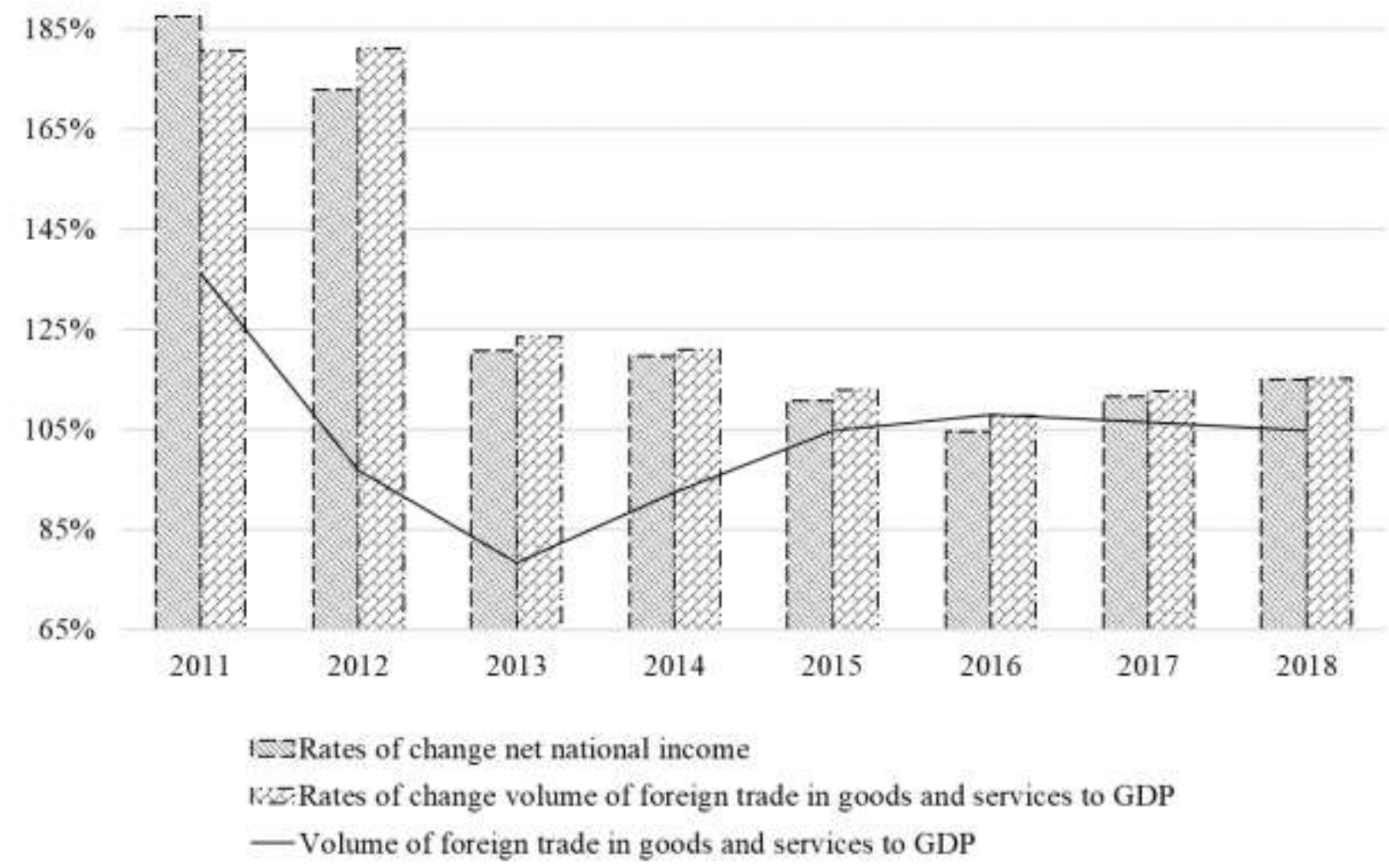

Figure 3. Rates of change of net national income, labor productivity by GDP and volume of foreign trade in goods and services to GDP 


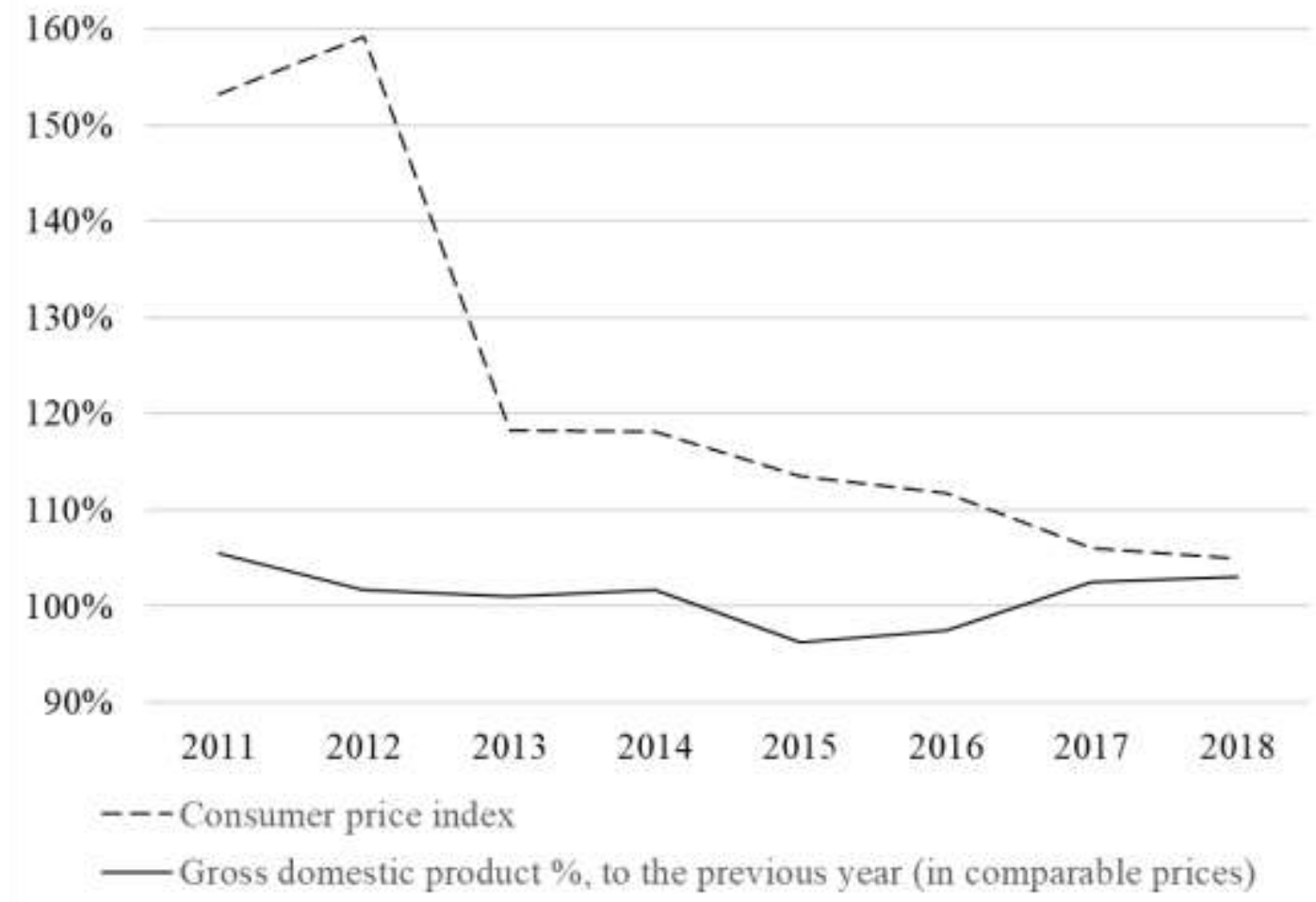

Figure 4. Consumer price index and gross domestic product (\%, to the previous year)

The consumer price index for the period under review was quite volatile and has only stabilized in 2015. The gross domestic product as a percentage of the previous year (in comparable prices) during the entire period under review was characterized by stable behavior and fluctuated between $96.2 \%$ and $105.5 \%$ (figure 4). At the same time, the growth rate of consumer prices is characterized by a downward trend, and the gross domestic product tends to increase in growth rates.

Indicators of environmental and resource efficiency of the economy help to track trends related to the elimination of dependence between resource consumption and economic growth. Figure 5 shows the dynamics of carbon efficiency linked to production and demand. In both cases, there is an increase in efficiency which is a key component of environmental efficiency in modern conditions. At the same time, the carbon efficiency linked to production has always been greater than or equal to the carbon efficiency linked to demand which is due to the peculiarities of calculating macroeconomic indicators (GDP is greater than gross national income by the amount of depreciation of long-term assets). In recent years, there has been a slowdown in the growth rate of these indicators (figure 5). 


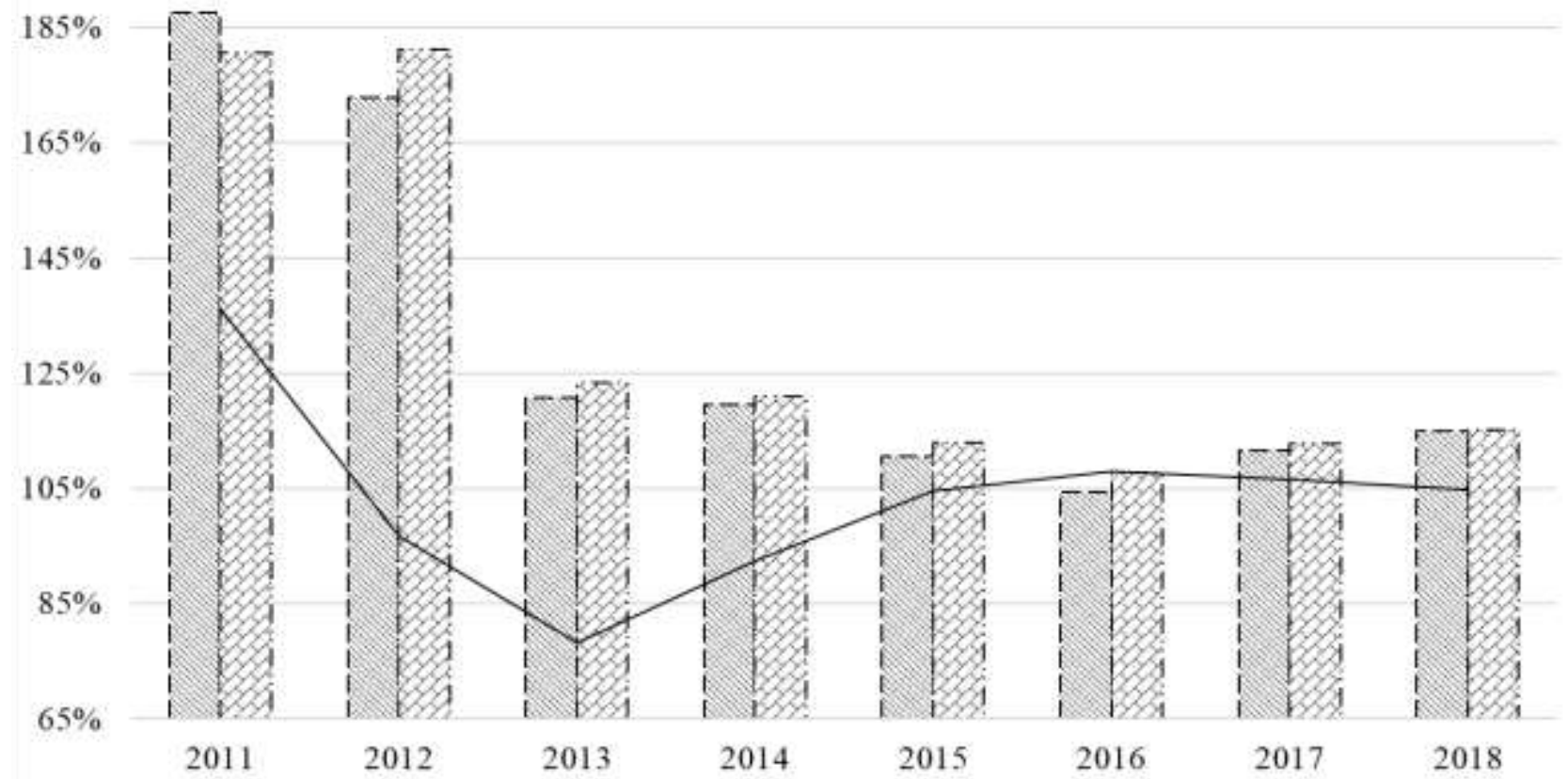

15 Rates of change net national income

$K Z$ Rates of change volume of foreign trade in goods and services to GDP

- Volume of foreign trade in goods and services to GDP

\section{Figure 5. Cconsumer price index and gross domestic product as a percentage}

With the confidence of 0.05 (the MannWhitney test), the equality of the average rates of change in the energy intensity of GDP and energy efficiency is shown. Energy efficiency in the Republic of Belarus is determined by the ratio of gross consumption of fuel and energy resources, expressed in mass of fuel equivalent to coal equivalent to gross domestic product (GDP in constant 2005 prices). GDP energy intensity is the ratio of gross consumption of fuel and energy resources to GDP (in constant prices of 2005) $\mathrm{kg}$ of conditional fuel, coal equivalent million rubles. Figure 6 shows the dynamics of these indicators. There is a decrease in energy intensity from 423.8 in 2010 to 380.5 in 2018 , a decrease of $9.8 \%$, which is quite high even by world standards. This indicates the transition of energy consumers, primarily industrial production, to energy-efficient technologies, which makes it possible to increase the level of return on energy resources consumed in the country's economy. On the other hand, during the period under review, there was a slowdown in the growth rate of energy efficiency from 2016 to 2018 . This is due to the crisis in the economy in general and in the investment sector in particular. Maintaining the current trend of increasing the energy efficiency of the economy will contribute to improving the sustainability of the country's energy and environmental systems, accelerating economic and social development, and improving the well-being of the population.

Copyright (C) 2021 Author(s), published by Vytautas Magnus University. This is an open access article distributed under the terms of the Creative Commons Attribution Non-Commercial 4.0 (CC BY-NC 4.0) license, which permits unrestricted use, distribution, and reproduction in any medium provided the original author and source are credited. The material cannot be used for commercial purposes. 


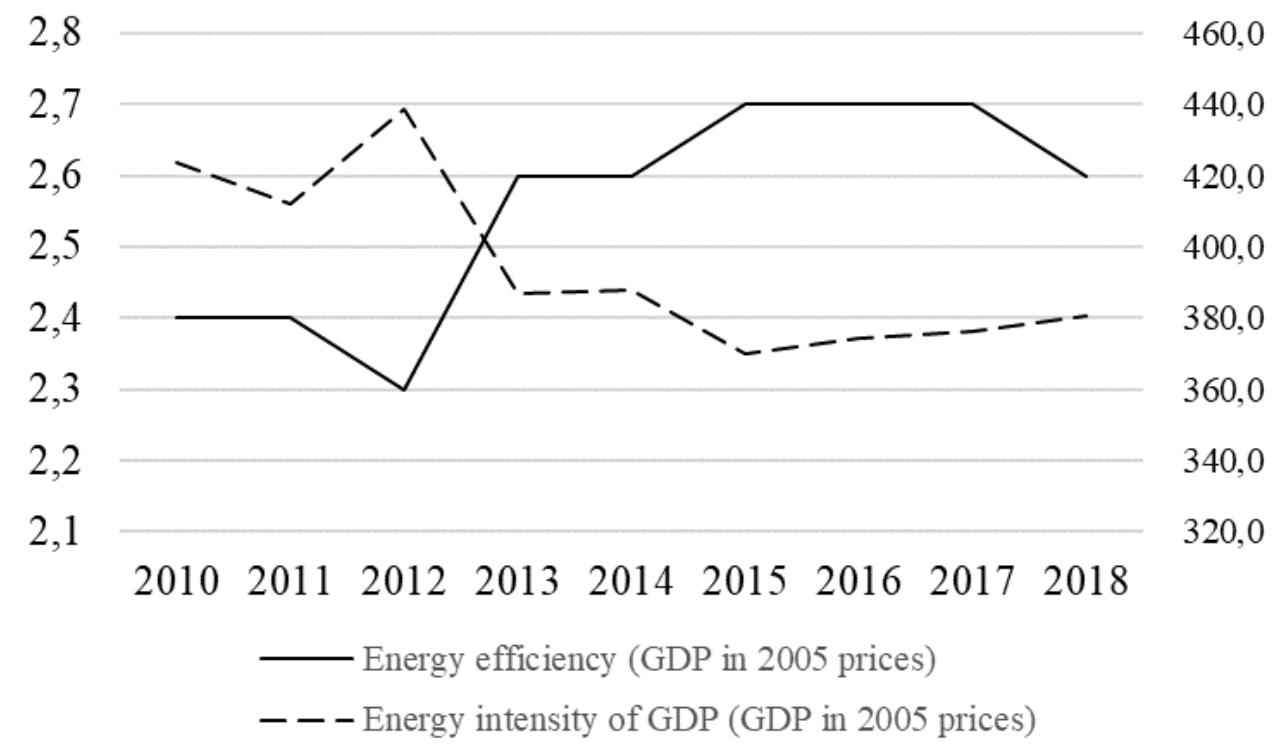

Figure 6. Dynamics of energy efficiency and energy intensity

The share of electric energy production increased by a factor of 3.5 during the period under review due to the use of renewable energy sources in the total volume of electric energy production. While in 2010 it was $0.4 \%$, in 2018 it became $1.8 \%$.

Solving problems related to waste recycling is an important aspect of protecting the environment. Figure 7 shows the indicators that characterize the intensity of waste generation in the Republic of Belarus and the regeneration of industrial waste. The decrease in the intensity of waste generation per unit of GDP was $80.6 \%$. The waste recovery rate increased to 0.5 in 2013 and decreased to 0.2 in 2015 and in 2018 remained at the level of 2010. The intensity of production waste generation per capita increased by $39.1 \%$ during $2010-2018$. Besides, the intensity of solid municipal waste generation per capita increased by $2.9 \%$. Trends in the growth of the rate of formation of the above-mentioned waste generation require regulation and competent management decisions at the state level.

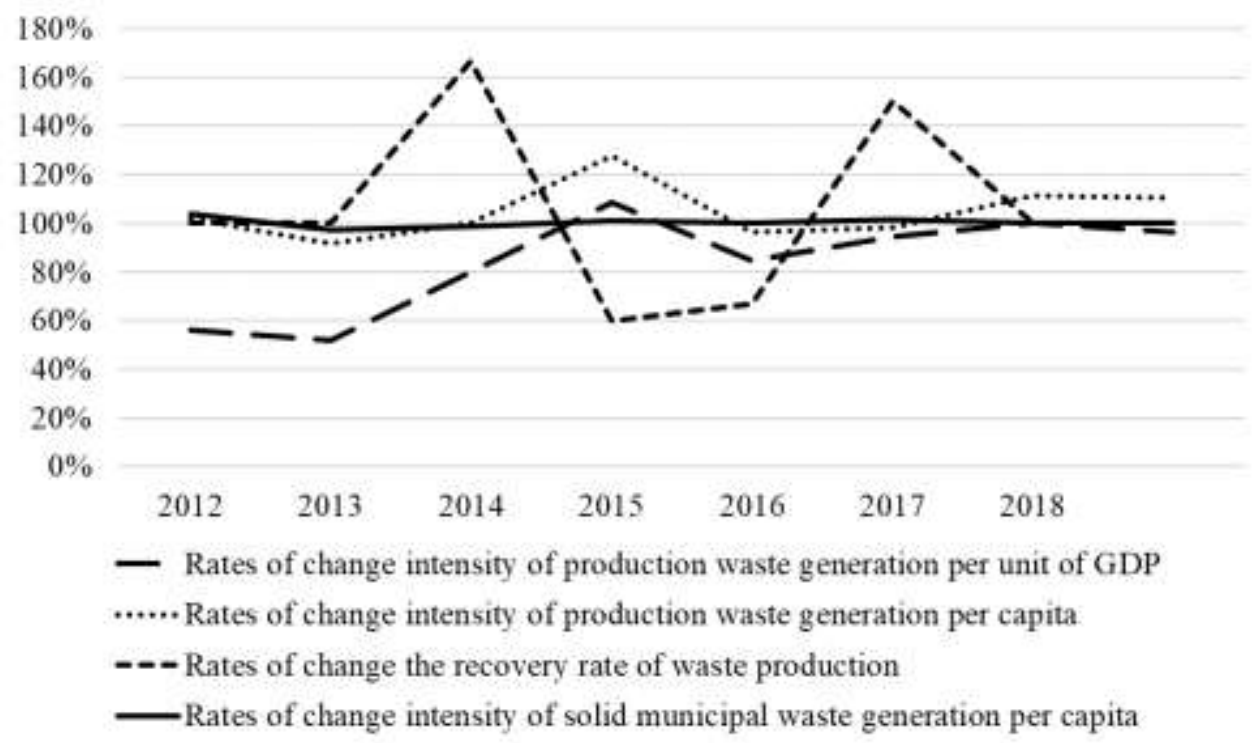

Figure 7. Dynamics of rates of indicators that characterize environmental problems of waste 
The share of total environmental expenditures in the gross domestic product of Belarus increased from $0.1 \%$ in 2017 to $0.7 \%$ in 2018. This reflects support for the transition to a green economy in the republic.

\section{Conclusions}

In the process of development of the green economy in the period $2010-2018$ in the Republic of Belarus, there is a certain success, which can be attributed to:

- reduction of energy density and increase of hydrocarbon efficiency in the presence of unstable economic growth;

- maintaining the concentration of pollutants in localities within acceptable standards in the conditions of increasing motorization of the population and business, as well as transit transport;

- $\quad$ preservation of the main natural assets in a state that provides sufficient environmental quality of life.

At the same time, there are several negative aspects of the development of the green economy in the Republic of Belarus. The perfect mechanism of green growth was not created. During the period under review, all the key changes are explained by measures of state administration of the economy, which in some cases had a positive effect. These measures include:

- introduction of stricter environmental standards for internal combustion engines;

- conversion of thermal power plants from fuel oil to gas, which is more environmentally friendly compared to other hydrocarbons;

- public investment in the Novogrudok wind farm has allowed a small increase in the share of electricity generation from renewable sources;
- introduction of a fee for waste collection and disposal. This tax is commonly known as the "cardboard fee" and a gradual increase in its rates had made it possible to improve the efficiency of waste collection and disposal, although this was achieved by increasing business revenues.

The practical measures that would stimulate the development of the green economy in Belarus:

- establishment of universal benefits for producers of eco-friendly goods and services (with a green certificate) in the form of income tax holidays and customs benefits, rather than individual benefits for individual enterprises;

- environmental certification of goods and production processes, which would make it possible to allocate objects for stimulation and support by state regulation measures;

- fixation of wholesale purchase prices for electricity in dollars or euros to reduce risks and attract foreign investment and technology;

- replacement of the environmental tax with auctions of emission rights, the limit of which is set on a territorial rather than production basis, would encourage investment in cleaning up emissions and effluents;

- replacement of the fee for waste disposal with a universal tax, which changes depending on the degree of waste-free technologies used;

- setting the rates of mineral extraction tax, excise taxes, and import duties depending on the target parameters of the structure of resources used;

- increasing the number of research grants, that stimulate the development of effective green technologies, and mechanisms to stimulate green economic development.

\footnotetext{
Copyright (C) 2021 Author(s), published by Vytautas Magnus University. This is an open access article distributed under the terms of the Creative Commons Attribution Non-Commercial 4.0 (CC BY-NC 4.0) license, which permits unrestricted use, distribution, and reproduction in any medium provided the original author and source are credited. The material cannot be used for commercial purposes.
} 


\section{References}

Makiela K. and Misztur T. (2012) Going Green versus Economic Performance // Engineering Economics. 2012.Vol. 23(2). Pp. 137-143.

Bashorina O. V., Tyomkina I. M. (2012) Perekhod k «zelenoj» ekonomike kak faktor ustojchivogo razvitiya i preodoleniya bednosti: mezhdunarodnyj i regional'nyj aspekty // Vestnik UrFU. Seriya ekonomika i upravlenie. 2012. №. 6. S. 49-60. http://elar.urfu.ru/bitstream/10995/54921/1/vestnik_2012_6_005.pdf [2021 01 20]

Porfir'ev B. N. (2013) «Zelenaya» ekonomika: realii, perspektivy i predely rosta. M.: Moskovskij Centr Karnegi, 2013. - 33 s. https://carnegieendowment.org/files/WP_Porfiriev_web.pdf [2021 01 20]

Kozhevnikova T. M., Ter Akopov S. G. (2013) «Zelenaya ekonomika» kak odno iz napravlenij ustoj-chivogo razvitiya. // Social'no-ekonomicheskie yavleniya i processy. 2013. № 3 (049). https://cyberleninka.ru/article/n/zelenayaekonomika-kak-odno-iz-napravleniy-ustoychivogo-razvitiya/viewer [2021 01 20]

Kozlov S.N. (2020) «Zelenaya» ekonomika, kak faktor ustojchivogo razvitiya regiona. // Vestnik NGIEI. 2020. №4. - S.55-65. https://cyberleninka.ru/article/n/zelenaya-ekonomika-kak-faktor-ustoychivogo-razvitiya-regiona/viewer. [2021 0120$]$

Bobylyov, S. N. (2019) Zelyonaya ekonomika i celi ustojchivogo razvitiya dlya Rossii: kollektivnaya monografiya / Pod nauch. red. S. N. Bobylyova, P. A. Kiryushina, O. V. Kudryavcevoj. - M.: Ekonomicheskij fakul'tet MGU imeni M. V. Lomonosova, 2019. - 284 s.https://www.econ.msu.ru/sys/raw.php?o=64435\&p=attachment [2021 01 20].

V.A. Rybak, A. Grib, A. SHokr. Analiz sushchnosti «zelenoj ekonomiki» i instrumentov upravleniya kachestvom okruzhayushchej sredy na primere Respubliki Belarusi // Interactive science | №4. 2016. - s. 97-107. URL: https://cyberleninka.ru/article/n/analiz-suschnosti-zelenoy-ekonomiki-i-instrumentov-upravleniya-kachestvom-okruzhayuschey-sredy-na-primere-respubliki-belarusi [2021 0120$]$

A. V. Lednickij, P. A. Protas. Razrabotka nacional'nogo plana dejstvij po vnedre-niyu principov «zelenoj» ekonomiki v lesnoe hozyajstvo Respubliki Belarus' do 2030 goda // Trudy BGTU. Seriya 5. № 2. 2019. - 5-11. URL: https://elib.belstu.by/handle/123456789/31900 [2021 01 20]

Directive of the President of the Republic of Belarus of 14 June 2007 № 3. - URL: https://president.gov.by/ru/documents/direktiva-3-ot-14-ijunja-2007-g-1399 [2021 01 20]

Program of Socio-Economic Development of the Republic of Belarus, and the Program of Activities of the Government of the Republic of Belarus for 2016-2020. - 2016. 124p. URL: https://www.economy.gov.by/en/state_programsen/

The National Strategy for Sustainable Development of the Republic of Belarus for the period up to 2035. - 2018. 148 p. URL: http://sdgs.by/kcfinder/upload/files/FINAL_SDG_Roadmap_ENG_27_06.pdf

EaP Green (2016), Оценка Зеленой Трансформации Экономики: Руководство для стран Восточного Партнерства ЕС. Париж. http://www.green-economieseap.org/ru/resources/EaP\%20GREEN_GGI\%20Guide_clean_RUS_Final.pdf

National Statistical Committee of the Republic of Belarus. https:/www.belstat.gov.by/ofitsialnaya-statistika/makroekonomika-i-okruzhayushchaya-sreda/okruzhayuschaya-sreda/pokazateli-zelenogo-rosta [2021 0120$].$

Nacional'nyj plan dejstvij po razvitiyu “zelenoj” ekonomiki v Respublike Bela-rus' do 2020 goda ot 03.01.2017 (2017) URL : http://minpriroda.gov.by/ru/news-ru/view/natsionalnyj-plan-dejstvij-po-razvitiju-zelenoj-ekonomiki-vrespublike-belarus-do-2020-goda-1958 [2021 0120$]$. 